\title{
Air versus water temperature of aquatic habitats in Delhi: Implications for transmission dynamics of Aedes aegypti
}

\author{
Gaurav Kumar, ${ }^{1}$ Veena Pande, ${ }^{2}$ Shweta Pasi, ${ }^{1}$ Vijay P. Ojha, ${ }^{1}$ Ramesh C. Dhiman ${ }^{1}$ \\ ${ }^{I}$ National Institute of Malaria Research (ICMR), Delhi; ${ }^{2}$ Kumaun University, Nainital, India
}

\begin{abstract}
The present study was planned to characterize the microclimate experienced by Aedes larvae in different breeding habitats by determining the temperature variations in water kept in containers during different months under natural conditions. The study was conducted in three municipal zones of Delhi. In each site, four types of container material (plastic, cement, iron and ceramic) were chosen for recording the water temperature in the containers. Daily air and water temperatures (mean, maximum and minimum values) recorded by $\mathrm{HOBO}$ and Tidbit data loggers, respectively, were compared using analysis of variance and Tukey's honest significant difference (HSD) tests. Mean monthly temperature of water varied from 16.9 to $33.0^{\circ} \mathrm{C}$ in tin containers, 17.3 to $35.6^{\circ} \mathrm{C}$ in plastic containers, 14.3 to $28.5^{\circ} \mathrm{C}$ in ceramic pots, 23.3 to $30.4^{\circ} \mathrm{C}$ in cemented underground tanks (UGT) and 15.8 to $35.1^{\circ} \mathrm{C}$ in cemented overhead tanks (OHTs). Corresponding values for the air temperature ranged from 17.7 to $36.1^{\circ} \mathrm{C}$. The difference
\end{abstract}

Correspondence: Ramesh C. Dhiman and Gaurav Kumar, National Institute of Malaria Research (ICMR), Sector 8, Dwarka, Delhi 110077, India.

Tel.: +91.011.2537404 - +91.011.2537418.

E-mail: r.c.dhiman@gmail.com - gauravnimr@gmail.com

Key words: Water temperature; Water container; Aedes mosquito; Breeding habitat; India.

Contributions: study designed by GK. Data collection and analysis by GK, written by GK and RCD. Manuscript reviewed and edited by GK, VP, SP, VPO and RCD.

Conflict of interest: the authors declare no potential conflict of interest.

Funding: the authors are thankful to the Director of the National Institute of Malaria Research (ICMR), Delhi, for providing the necessary funding support to carry out the study.

Received for publication: 10 May 2018.

Revision received: 7 September 2018.

Accepted for publication: 1 October 2018.

CCopyright G. Kumar et al., 2018

Licensee PAGEPress, Italy

Geospatial Health 2018; 13:707

doi:10.4081/gh.2018.707

This article is distributed under the terms of the Creative Commons Attribution Noncommercial License (CC BY-NC 4.0) which permits any noncommercial use, distribution, and reproduction in any medium, provided the original author(s) and source are credited. between temperature of water in the containers and air temperature was highest for ceramic pots. Daily mean, maximum and minimum temperatures recorded by different data loggers differed significantly $(\mathrm{P}<0.05)$. When Tukey HSD test was applied for data analysis, the daily mean air temperature differed significantly from the water temperature in tin and ceramic pots as well as cemented OHTs. The temperature of water in the different breeding habitats investigated was lower than the air temperature. Moreover, actual air temperature as recorded by HOBO was higher than the temperature recorded by local weather stations. Considering the ongoing climate change, cemented UGT and earthen pots may be more productive breeding habitats for the Aedes mosquito in the near future, while plastic and cemented OHTs might no longer be suitable for Aedes breeding.

\section{Introduction}

Mosquitoes are important vectors of diseases like dengue, malaria, Japanese encephalitis, etc. that cause a great amount of morbidity and mortality among human populations. They are poikilothermic in nature and temperature affects several aspects of their biology like development, longevity, gonotrophic cycle and vector competence (Calado and Navarro-Silva, 2002; Rúa et al., 2005; Paaijmans et al., 2011; Ciota et al., 2014). Mosquito breeds in aquatic habitats and their development from egg to pupae are completed in water, whose temperature affects the fitness of the emerging adults (Oda et al., 2002; Westbrook et al., 2010). Several studies have shown the effect of water temperature on larval biology in a number of mosquitoes including Aedes aegypti (Bar-Zeev, 1958; Tun-Lin et al., 2000; Mohammed and Chadee, 2011).

Ae. aegypti, the principal vector of dengue and chikungunya in India, generally breeds in a variety of habitats either natural or man-made. Man-made habitats are the containers made of different materials, i.e. plastic, iron, cement, glass, ceramic, rubber, etc. Laboratory studies have shown that there is a significant difference between the temperature of water in the breeding containers and the environmental temperature. Moreover, inter-container temperature variations also exist (Kumar et al., 2016a). The air temperature varies significantly during different months resulting in differences between temperature of air and water. Studies with Anopheles mosquitoes have shown that the water temperature in breeding habitats differs from air temperature (Paaijmans et al., 2008). In Kenya, the mean water temperature of the breeding habitats was 4-6 ${ }^{\circ} \mathrm{C}$ higher than corresponding mean air temperatures (Paaijmans et al., 2010; Paaijmans and Thomas, 2013). Moreover, diurnal variations in temperature also exist that may affect the life history traits of mosquitoes and disease transmission (Lambrechts et al., 2011; Mohammad and Chadee, 2011; Carrington et al., 
2013b). Most of the studies undertaken so far have recorded and analyzed the variations of temperature only for a limited duration (Paaijmans et al., 2010; Paaijmans and Thomas, 2013) rather than the whole year. There may be monthly differences in the temperature of water with respect to air temperature that may affect larval breeding. Hence, there is a need to generate longitudinal data for the variations in temperature between air and water affecting the development of Ae. aegypti.

The present study was undertaken to find out the variations in temperature of water in container material during different months under natural conditions that may affect breeding and development of Ae aegypti. Further, understanding the impact of temperature of different environmental niches with regard to Ae. aegypti population dynamics will help improving our knowledge towards dengue transmission dynamics.

\section{Materials and Methods}

Administratively, Delhi is divided into 12 municipal zones which fall under three municipal corporations - East MCD, North MCD and South MCD. Based on the prevalence of dengue, three zones namely, the South zone, the Shahdara North zone and the Najafgarh zone were selected for the study (Figure 1). At each site, four types of containers based on the construction material (plastic, cement, iron and ceramic) were chosen for recording the temperature of container-held water. In the Shahdara zone, cemented containers were mostly overhead cement tanks (OHTs), while in the other two zones cemented containers were underground tanks (UGTs). In each container, one temperature data logger, the UTBI001 Tidbit v2 (Onset, Cape Cod, MA, USA) was placed nearly 20 $\mathrm{cm}$ below the water surface to record hourly temperature. Volume of water in all the containers was maintained by adding water after every one or two days. Air temperature was also recorded by installing HOBO data loggers, Onset Temperature/RH data logger U14-001 (Onset, Cape Cod, MA, USA), which were placed on outer wall of room under shade. The data was recorded from March 2015 to May 2016. Overall, 16 Tidbit data loggers were installed for recording water temperature at different sites and three HOBO loggers were installed for recording the air temperature. The position of the data loggers was recorded using a global positioning system instrument from Garmin (https://www. garmin.com/en-US/company/about/). Recorded data were downloaded on a monthly basis from the data loggers using a computer. Monthly weather data from the Delhi weather station was downloaded from the National Oceanic and Atmospheric Administration's (NOAA) National Climate Data Center.

Daily maximum, minimum and mean temperatures were calculated for each of the loggers. Additionally, monthly maximum, minimum and mean temperatures were also calculated. Data from NOAA were used to analyse the differences in temperature data recorded by $\mathrm{HOBO}$ and that provided meteorologically. Due to loss or technical problems in $\mathrm{HOBO}$ and Tidbit data loggers installed in the Najafgarh zone, air and water temperature of plastic containers could not be recorded for the duration of March-April 2015. In the Shahdara zone, there was a loss of water temperature data for plastic containers for the period April- May 2016.

Daily and monthly mean, maximum and minimum temperatures recorded by the HOBO and Tidbit data loggers were compared using the analysis of variance (ANOVA) approach (https://www.statisticshowto.datasciencecentral.com/probability- and-statistics/hypothesis-testing/anova/) and also the Tukey honestly significant difference (HSD) test (https://www.statisticshowto.datasciencecentral.com/tukey-test-honest-significant-difference/tests). Variations in the diurnal temperature range were also analysed statistically using ANOVA and Tukey HSD. Comparison of the temperature recorded by the local weather station and HOBO data loggers was done using the paired sample t test (http://www.statisticssolutions.com/manova-analysis-paired-sample-t-test/). All the analyses was done with help of SPSS 16.0 statistical software and online web statistical calculator (astatsa.com).

\section{Results}

The temperature of water in different containers was generally lower than the temperature of air recorded by HOBO (Figure 2). The mean monthly temperature of water varied from 16.9 to 33.0 ${ }^{\circ} \mathrm{C}$ in tin containers, 17.3 to $35.6{ }^{\circ} \mathrm{C}$ in plastic containers, 14.3 to $28.5{ }^{\circ} \mathrm{C}$ in ceramic pots, 23.3 to $30.4{ }^{\circ} \mathrm{C}$ in cemented UGTs and 15.8 to $35.1^{\circ} \mathrm{C}$ in cemented OHTs (Table 1). Corresponding values for the air temperature ranged from 17.7 to $36.1{ }^{\circ} \mathrm{C}$. Temperature of water in cemented UGTs was observed to be higher than the temperature of air from October to March. Further, the difference between the water temperature in containers and air temperature was highest for ceramic pots. Daily mean, maximum and minimum temperatures recorded by different data loggers differed significantly $(\mathrm{P}<0.05)$. When results were analysed using Tukey HSD test, significant differences were observed between the daily mean air temperature and water temperature in different containers such as tin, ceramic pot and cemented OHT (Tables 1 and 2). Similarly, daily maximum and minimum air temperatures differed significantly $(\mathrm{P}<0.05)$ from water temperature in tin, ceramic pots and cemented OHT. Interestingly, the difference between air and water temperature in plastic containers was insignificant for the mean,

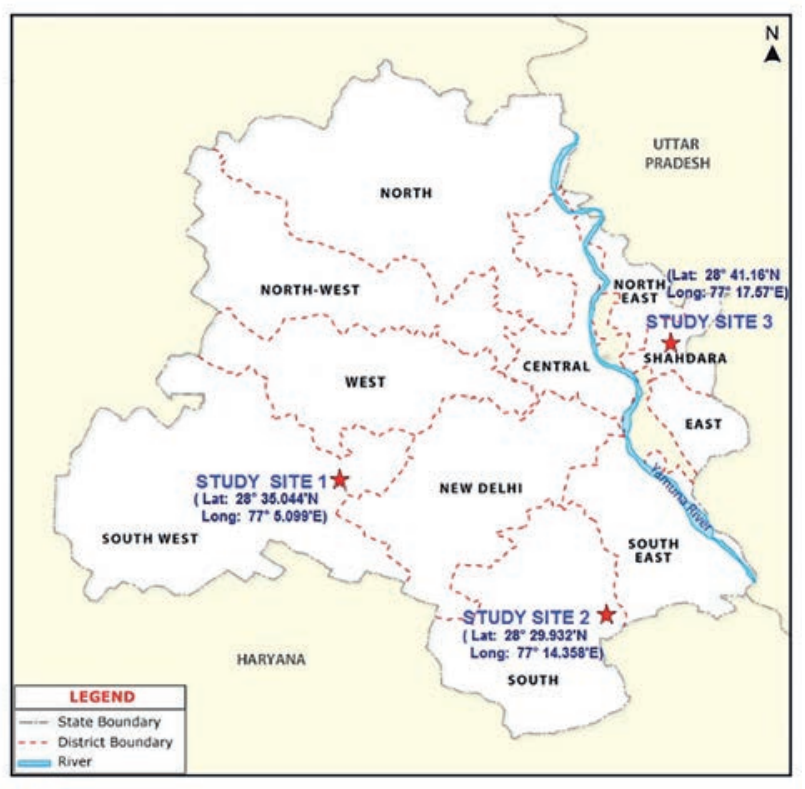

Figure 1. Map of Delhi showing the study sites with latitude and longitude. 
maximum and minimum daily temperatures.

Temperature recorded by the local weather station was generally lower than the temperature recorded by HOBOs installed at three different zones. When the test was applied, a significant variation $(\mathrm{P}<0.05)$ was observed in temperature recorded by $\mathrm{HOBO}$ and temperature recorded by local weather stations in the South and Shahdara North zones except in the Najafgarh zone (Figure 3).

\section{Discussion}

This study has elucidated the variations observed in temperature of water in different breeding containers for the Aedes mosquito with respect to corresponding air temperatures. The temperature of water in all types of containers differed significantly from air temperature except for plastic containers. Similar findings have been reported under laboratory conditions where the temperature of water in four different containers was recorded and found to be lower than the temperature of environmental chamber

Table 1. Monthly variations in mean water temperature in different containers with air temperatures.

\begin{tabular}{|c|c|c|c|c|c|c|c|c|c|c|c|c|}
\hline \multirow[t]{3}{*}{ Month } & \multicolumn{2}{|c|}{$\begin{array}{l}\text { HOBO measurements } \\
\text { of the air temperature } \\
(\mathrm{n}=3)\end{array}$} & \multicolumn{10}{|c|}{ Temperature of water in different containers } \\
\hline & \multirow[b]{2}{*}{$\begin{array}{l}\text { Mean } \\
\text { temp. }\end{array}$} & \multirow[b]{2}{*}{$\pm \mathrm{SE}$} & \multicolumn{2}{|c|}{$\begin{array}{l}\text { Plastic } \\
(\mathrm{n}=3)\end{array}$} & \multicolumn{2}{|c|}{$\begin{array}{c}\text { Cemented UGT } \\
\qquad(\mathrm{n}=2)\end{array}$} & \multicolumn{2}{|c|}{$\begin{array}{l}\text { Cemented OHT } \\
\qquad(\mathrm{n}=1)\end{array}$} & \multicolumn{2}{|c|}{$\begin{array}{c}\text { Ceramic pot } \\
(\mathrm{n}=3)\end{array}$} & \multicolumn{2}{|c|}{$\operatorname{Tin}_{(\mathrm{n}=3)}$} \\
\hline & & & $\begin{array}{l}\text { Mean } \\
\text { temp. }\end{array}$ & $\pm \mathrm{SE}$ & $\begin{array}{l}\text { Mean } \\
\text { temp. }\end{array}$ & $\pm \mathrm{SE}$ & $\begin{array}{l}\text { Mean } \\
\text { temp. }\end{array}$ & $\pm \mathrm{SE}$ & $\begin{array}{l}\text { Mean } \\
\text { temp. }\end{array}$ & $\pm \mathrm{SE}$ & $\begin{array}{l}\text { Mean } \\
\text { temp. }\end{array}$ & $\pm \mathrm{SE}$ \\
\hline Mar-15 & 24.1 & 0.48 & 23.5 & 0.6 & 24.6 & 2.8 & 21.3 & - & 20.5 & 0.2 & 22.7 & 0.7 \\
\hline Apr-15 & 30.7 & 0.42 & 29.9 & 0.9 & 26.9 & 1.8 & 29.1 & - & 25.1 & 0.9 & 28.8 & 0.7 \\
\hline May-15 & 36.1 & 1.11 & 35.6 & 1.3 & 29.1 & 0.4 & 35.1 & - & 27.2 & 0.5 & 31.9 & 1.9 \\
\hline Jun-15 & 34.2 & 1.03 & 33.7 & 1.0 & 29.8 & 0.0 & 33.3 & - & 28.2 & 0.2 & 31.2 & 1.5 \\
\hline Jul-15 & 31.3 & 0.54 & 31.4 & 0.6 & 30.1 & 0.3 & 30.9 & - & 28.5 & 0.2 & 29.9 & 0.6 \\
\hline Aug-15 & 31.0 & 0.34 & 30.8 & 0.8 & 30.2 & 0.3 & 30.7 & - & 28.4 & 0.7 & 29.3 & 0.2 \\
\hline Sep-15 & 31.5 & 0.54 & 32.0 & 1.1 & 30.4 & 0.5 & 31.4 & - & 28.1 & 1.1 & 29.3 & 0.7 \\
\hline Oct-15 & 29.1 & 0.27 & 29.3 & 0.7 & 29.3 & 0.1 & 28.6 & - & 24.3 & 0.7 & 27.6 & 0.6 \\
\hline Nov-15 & 23.6 & 0.56 & 24.6 & 0.6 & 27.4 & 1.7 & 22.6 & - & 18.8 & 0.2 & 22.4 & 0.4 \\
\hline Dec-15 & 18.0 & 1.05 & 18.7 & 0.9 & 24.8 & 3.4 & 17.0 & - & 14.3 & 0.1 & 17.7 & 1.1 \\
\hline Jan-16 & 17.7 & 1.40 & 17.3 & 0.9 & 23.3 & 4.1 & 15.8 & - & 14.7 & 0.6 & 16.9 & 1.2 \\
\hline Feb-16 & 20.8 & 0.47 & 20.4 & 0.7 & 23.3 & 3.9 & 19.3 & - & 16.7 & 0.1 & 20.6 & 1.5 \\
\hline Mar-16 & 25.9 & 0.01 & 25.5 & 1.1 & 25.2 & 2.9 & 24.5 & - & 21.0 & 0.7 & 26.0 & 1.6 \\
\hline Apr-16 & 32.6 & 0.74 & 32.5 & 0.4 & 27.8 & 1.5 & 30.9 & - & 26.0 & 1.8 & 33.0 & 1.7 \\
\hline
\end{tabular}

SE, standard error; UGT, underground tank; OHT, overhead tank.

Table 2. Effects of container material on mean, maximum and minimum water temperature in response to air temperature.

\begin{tabular}{|c|c|c|c|c|}
\hline Temperature & Treatment & $\begin{array}{l}\text { Tukey HSD } \\
\text { Q statistic }\end{array}$ & $\begin{array}{c}\text { Tukey HSD } \\
\text { P value }\end{array}$ & $\begin{array}{l}\text { Tukey HSD } \\
\text { inference }\end{array}$ \\
\hline Daily mean & $\begin{array}{l}\text { Air temperature X tin } \\
\text { Air temperature X plastic } \\
\text { Air temperature X ceramic pot } \\
\text { Air temperature X cemented UGT } \\
\text { Air temperature X cemented OHT }\end{array}$ & $\begin{array}{l}5.2720 \\
0.5078 \\
17.4300 \\
1.2141 \\
4.3979\end{array}$ & $\begin{array}{l}0.002 \\
0.899 \\
0.001 \\
0.899 \\
0.023\end{array}$ & $\begin{array}{l}{ }^{* *} \mathrm{P}<0.01 \\
\text { insignificant } \\
{ }^{* * \mathrm{P}}<0.01 \\
\text { insignificant } \\
\quad * \mathrm{P}<0.05\end{array}$ \\
\hline Daily maximum & $\begin{array}{l}\text { Air temperature X tin } \\
\text { Air temperature X plastic } \\
\text { Air temperature X ceramic pot } \\
\text { Air temperature X cemented UGT } \\
\text { Air temperature X cemented OHT }\end{array}$ & $\begin{array}{c}8.6500 \\
1.1424 \\
20.8799 \\
8.8935 \\
11.5834 \\
\end{array}$ & $\begin{array}{l}0.001 \\
0.899 \\
0.001 \\
0.001 \\
0.001\end{array}$ & $\begin{array}{l}{ }^{* *} \mathrm{P}<0.01 \\
\text { insignificant } \\
{ }^{* * \mathrm{P}}<0.01 \\
{ }^{* * \mathrm{P}}<0.01 \\
{ }^{* * \mathrm{P}}<0.01\end{array}$ \\
\hline Daily minimum & $\begin{array}{l}\text { Air temperature X tin } \\
\text { Air temperature X plastic } \\
\text { Air temperature X earthen pot } \\
\text { Air temperature X cemented UGT } \\
\text { Air temperature X cemented OHT }\end{array}$ & $\begin{array}{c}3.3153 \\
0.0532 \\
14.2695 \\
0.3975 \\
8.2628\end{array}$ & $\begin{array}{l}0.176 \\
0.899 \\
0.001 \\
0.899 \\
0.001\end{array}$ & $\begin{array}{l}\text { insignificant } \\
\text { insignificant } \\
{ }^{* * P}<0.01 \\
\text { insignificant } \\
{ }^{* * P}<0.01\end{array}$ \\
\hline
\end{tabular}

HSD, honest significant difference; UGT, underground tanks; OHT, overhead tanks. 
(Kumar et al., 2016a). In contrast, the water temperatures of artificial water pools made in the ground were generally higher than the corresponding air temperatures in a field study conducted in Kenya for determining the development rate of the Anopheles mosquito (Paaijmans et al., 2010). In that study, the water temperature was recorded in open ground water pools directly exposed to sunlight, while in the current study the water temperature was recorded in different containers covered with a lid and hence not exposed to direct sunlight.

The temperature recorded by the local weather station was generally lower than the temperature recorded by HOBO installed at three different zones. The finding is in line with previous studies wherein similar differences were observed between temperatures recorded locally and those recorded by weather stations (Paiijmans and Thomas, 2011; Cator et al., 2013). These variations occur due to the variation in location of weather station and data logger sites highlighting the importance of micro niches for understanding the dynamics of vector populations in the context of temperature variability. Data loggers at weather stations are generally installed in an open space in an instrument shelter (Stevenson screen), while

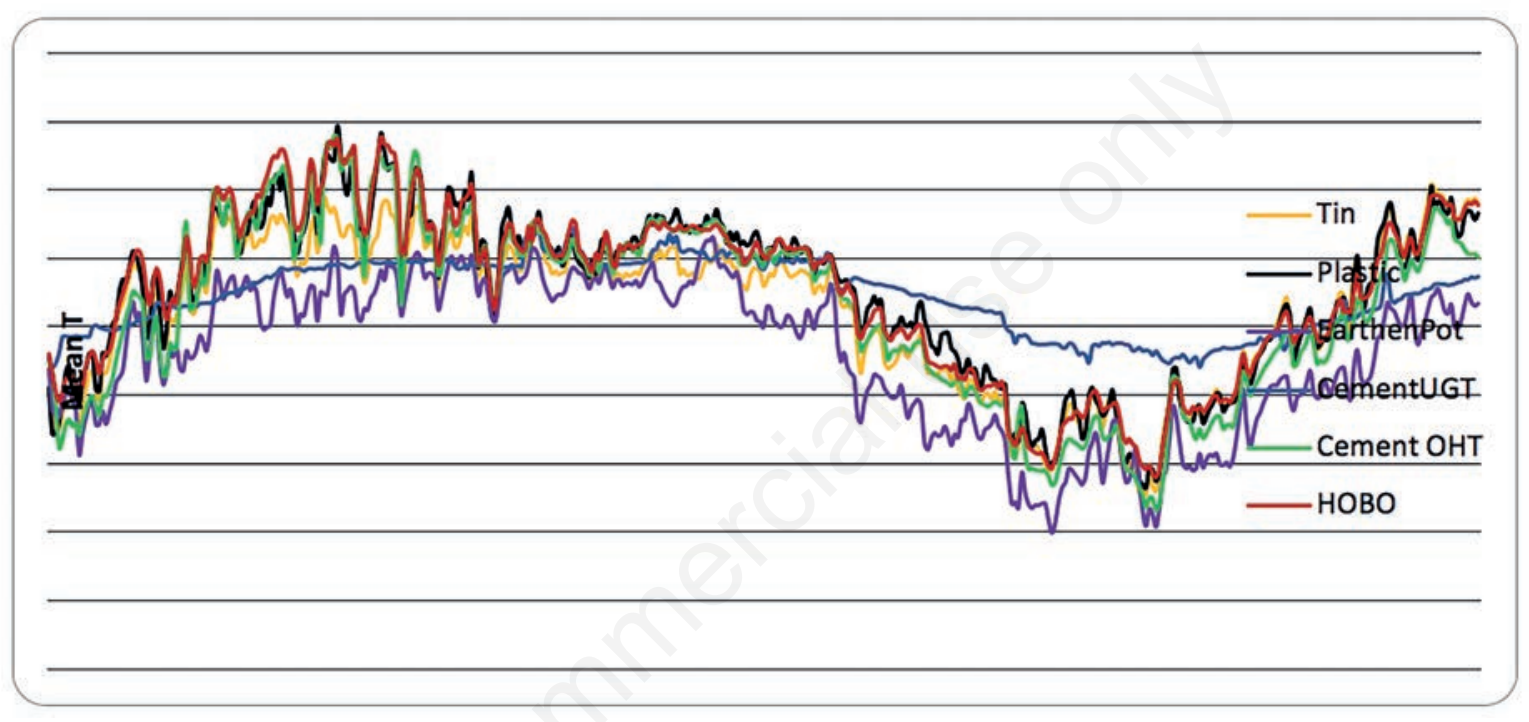

Figure 2. Daily mean temperature of water in different containers with the corresponding air temperatures. UGT, underground tank; OHT, overhead tank.

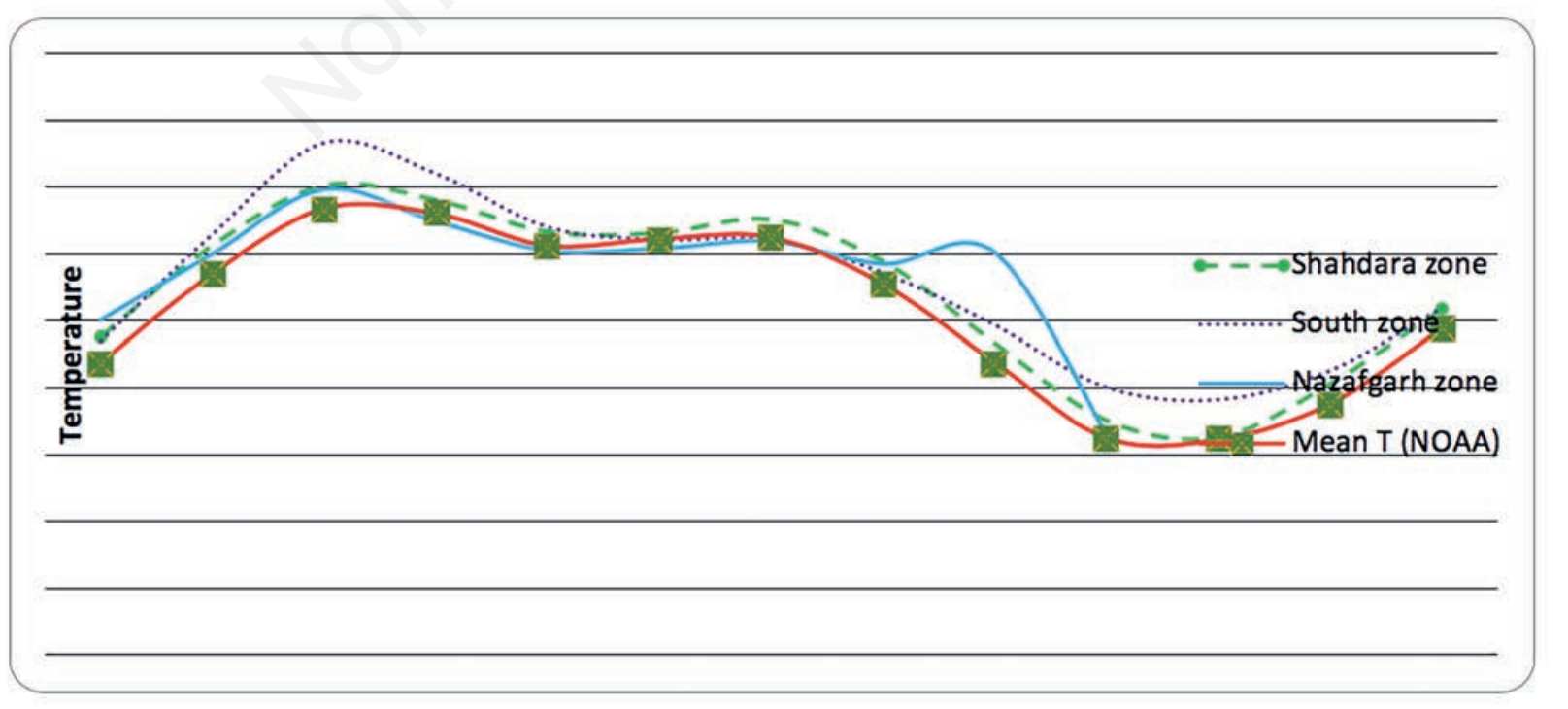

Figure 3. Mean monthly temperature recorded by National Oceanic and Atmospheric Administration's (NOAA) and HOBO installed at three zones of Delhi. 
the HOBOs in our study were installed on the outer wall of houses situated in a dense building locality.

An important finding of the study was the temperature of water during winter months (December-February) which was significantly higher $\left(23.3-24.8^{\circ} \mathrm{C}\right)$ in cemented UGTs than the temperature in other containers $\left(14.2-20.6{ }^{\circ} \mathrm{C}\right)$. It indicates that the temperature remains suitable for the breeding and development of $A e$. aegypti in UGTs even in winter months. In a recent study, it was observed that Ae. aegypti did not oviposit at temperatures below 20 ${ }^{\circ} \mathrm{C}$ and was reproductively inefficient at low temperatures (Carrington et al., 2013a). The same study reported that it took 31.7 days for development from egg to pupa at $16^{\circ} \mathrm{C}$. Thus, adult Aedes mosquitoes developing in UGTs will be more efficient than mosquitoes developing in other types of containers during the winter months and may sustain populations of Aedes during the nontransmission period of dengue. During the peak summer months (April-June), the water temperature in UGTs $\left(26.9-29.8^{\circ} \mathrm{C}\right)$ and ceramic pots $\left(25.1-28.2^{\circ} \mathrm{C}\right)$ was near the optimum for Aedes larval development $\left(27 \pm 1^{\circ} \mathrm{C}\right)$. While in plastic containers and cemented OHTs, the water temperature reached the upper threshold for Aedes development. It suggests that plastic and cemented OHTs are not suitable for the growth of Aedes.

One limitation of the current study was that plastic containers selected were OHTs. It has been previously reported that plastic containers (Plastic tub/drum/tanks/OHT) are the most positive containers and remains so throughout the year (Singh et al., 2014; Kumar et al., 2016b). Hence, further investigations should incorporate plastic containers used for storing water inside the houses like plastic drums, buckets etc., vis-a-vis plastic containers kept on the rooftop.

So far, only a few studies have been undertaken to understand the actual environment experienced by larvae of mosquito vectors. These studies have been done mostly on anopheline vectors (Paiijmans et al., 2010; Cator et al., 2013; Asare et al., 2016). There is a scarcity of literature on environmental temperature conditions experienced by Ae. aegypti under natural field conditions (Hemme et al., 2009), and it is an important aspect as temperature required for larval development is a key factor which not only determines the life history traits (Carrington et al., 2013b) but also affects the insecticide resistance status (Polson et al., 2012) and vectorial capacity of adult mosquitoes (Alto and Bettinardi, 2013). Hence, the current study was an effort in understanding the temperature dynamics experienced by Aedes larvae in breeding containers made up of different materials. Here, environmental temperatures ranged from $17.7^{\circ} \mathrm{C}$ to $36.1^{\circ} \mathrm{C}$, and the corresponding water temperatures ranged from $14.3{ }^{\circ} \mathrm{C}$ to $35.5^{\circ} \mathrm{C}$ in different breeding containers. Other studies have reported that $>35^{\circ} \mathrm{C}$ temperature of water is inimical for Aedes larval development (Kumar et al., 2016a). The Intergovernment Panel on Climate Change (IPCC) has projected increases in average temperatures in tropical countries of $1.4{ }^{\circ} \mathrm{C}-5.8{ }^{\circ} \mathrm{C}$ by the year 2100 due to climate change (IPCC, 2007). The projected increase in temperature is expected to affect the development and survival of Ae. Aegypti larvae. In the present study we observed that the mean temperature of water in plastic and cemented overhead tanks reached the threshold temperature during the summer season. Hence, these containers may no longer be suitable for the breeding of Aedes in the near future. Further, cemented UGTs and ceramic pots may emerge as preferred containers for the development of Aedes larvae.

\section{Conclusions}

The current study has characterized the microclimate experienced by the Aedes larvae in different breeding containers. The temperature of water in different breeding habitats was found to be lower than the air temperature. Moreover, actual air temperatures as recorded by home data loggers were generally higher than the temperature recorded by local weather stations. Considering the ongoing changes in climate, cemented UGTs and ceramic pots may emerge as better breeding habitats for Aedes mosquito in near future while plastic and cemented OHTs might no longer be suitable for larval breeding. The results of this study will be useful in developing temperature-driven dynamic dengue risk models and improvement of early forecast systems.

\section{References}

Alto BW, Bettinardi D, 2013. Temperature and dengue virus infection in mosquitoes: independent effects on the immature and adult stages. Am J Trop Med 88:497-505.

Asare EO, Tompkins AM, Amekudzi LK, Ermert V, Redl R, 2016. Mosquito breeding site water temperature observations and simulations towards improved vector-borne disease models for Africa. Geospat Health 11:67-77.

Bar-Zeev M, 1958. The effect of temperature on the growth rate and survival of the immature stages of Aedes aegypti (L.). Bull Entomol Res 49:157-63.

Calado DC, Navarro-Silva MA, 2002. Influência da temperatura sobre a longevidade, fecundidade e atividade hematofágica de Aedes (Stegomyia) albopictus Skuse, 1894 (Diptera, Culicidae) sob condições de laboratório. Rev Bras Ent 46:938.

Carrington LB, Armijos MV, Lambrechts L, Barker CM, Scott TW, 2013a. Effects of fluctuating daily temperatures at critical thermal extremes on Aedes aegypti life-history traits. PLoS One 8:e58824.

Carrington LB, Seifert SN, Willits NH, Lambrechts L, Scott TW, 2013b. Large diurnal temperature fluctuations negatively influence Aedes aegypti (Diptera: Culicidae) life-history traits. J Med Entomol 50:43-51.

Cator LJ, Thomas S, Paaijmans KP, Ravishankaran S, Justin JA, Mathai MT, Read FA, Thomas MB, Eapen A, 2013. Characterizing microclimate in urban malaria transmission settings: a case study from Chennai, India. Malar J 12:84.

Ciota AT, Matacchiero AC, Kilpatrick AM, Kramer LD, 2014. The effect of temperature on life history traits of Culex mosquitoes. J Med Entomol 51:55-62.

Hemme RR, Tank JL, Chadee DD, Severson DW, 2009. Environmental conditions in water storage drums and influences on Aedes aegypti in Trinidad West Indies. Acta Trop 112:59-66.

Intergovernment Panel on Climate Change (IPCC), 2007. In: Parry ML, Canziani OF, Palutikof JP, van der Linden PJ, Hanson CE, eds. Contribution of Working Group II to the Fourth Assessment Report of the Intergovernmental Panel on Climate Change, 2007. Cambridge, UK - New York, USA: Cambridge University Press.

Kumar G, Singh RK, Pande V, Dhiman RC, 2016a. Impact of container material on the development of Aedes aegypti larvae at 
different temperatures. J Vector Borne Dis 53:144-8.

Kumar G, Singh RK, Pande V, Ojha VP, Das R, Haq S, 2016 b. Prevalence of dengue vector Aedes aegypti and its significance in dengue transmission in Delhi. Res J PharmaC Biol Chem Sci 7:755-60.

Lambrechts L, Paaijmans KP, Fansiri T, Carrington LB, Kramer LD, Thomas MB, Scott MB, 2011. Impact of daily temperature fluctuations on dengue virus transmission by Aedes aegypti. Proc Natl Acad Sci USA 108:7460-5.

Mohammed A, Chadee DD, 2011. Effects of different temperature regimens on the development of Aedes aegypti (L.) (Diptera: Culicidae) mosquitoes. Acta Trop 119:38-43.

Oda T, Eshita Y, Uchida K, Mine M, Kurokawa K, Ogawa Y, Kato K, Tahara H, 2002. Reproductive activity and survival of Culex pipiens pallens and Culex quinquefasciatus (Diptera: Culicidae) in Japan at high temperature. J Med Entomol 39:185-90.

Paaijmans KP, Imbahale SS, Thomas MB, Takken W, 2010. Relevant microclimate for determining the development rate of malaria mosquitoes and possible implications of climate change. Malaria J 9:196.

Paaijmans KP, Jacobs AFG, Takken W, Heusinkveld BG, Githeko AK, Dicke M, Holtslag AAM, 2008. Observations and model estimates of diurnal water temperature dynamics in mosquito breeding sites in western Kenya. Hydrol Proces 22:4789801.

Paaijmans KP, Thomas MB, 2011. The influence of mosquito rest- ing behavior and associated microclimate for malaria risk. Malar J 10:183.

Paaijmans KP, Thomas MB, 2013. Relevant temperatures in mosquito and malaria biology. In: Takken W, Koenraadt CJM, eds. Ecology of parasitevector interactions. Wageningen, NL: Springer. pp 103-121.

Polson KA, Brogdon WG, Rawlins SC, Chadee DD, 2012. Impact of environmental temperatures on resistance levels of Organophosphate insecticides in Aedes aegypti. Pan Am J Public Health 32:1-8.

Rúa GL, Quiñones ML, Vélez ID, Zuluaga JS, Rojas W, Poveda G, Ruiz D, 2005. Laboratory estimation of the effects of increasing temperatures on the duration of gonotrophic cycle of Anopheles albimanus (Diptera: Culicidae). Mem Inst Oswaldo Cruz [Internet] 100:515-20.

Singh RK, Mittal PK, Kumar G, Dhiman RC, 2014. Prevalence of Aedes mosquitoes in various localities of Delhi during dengue transmission season. Entomol Appl Sci Lett 1:16-21.

Tun-Lin W, Burkot TR, Kay BH, 2000. Effects of temperature and larval diet on development rates and survival of the dengue vector Aedes aegypti in north Queensland Australia. Med Vet Entomol 14:31-7.

Westbrook CJ, Reiskind MH, Pesko KN, Greene KE, Lounibos LP, 2010. Larval environmental temperature and the susceptibility of Aedes albopictus Skuse (Diptera: Culicidae) to Chikungunya virus. Vector Borne Zoonotic Dis 10:241-7. 